\title{
INCIDENCE OF MUSCULOSKELETAL DISORDERS IN TRAIN COMMUTERS
}

Vrushali Rajesh Patil ${ }^{1}$, Satish Pimpale *2, Ajay kumar ${ }^{3}$.

${ }^{1}$ UG Intern, DPO's NETT college of physiotherapy, Thane, India.

${ }^{* 2}$ Assistant Professor, DPO's NETT college of physiotherapy, Thane, India.

${ }^{3}$ Principal, DPO's NETT College of physiotherapy, Thane, India.

\section{ABSTRACT}

Background: A Musculoskeletal disorders (MSD's) arises not directly from an acute or instantaneous event but arising gradually and chronically. Indian railway is the world's largest railway system; in Mumbai the daily ridership is about 7.585 million. As Mumbai is India's commercial and financial centre therefore, the network is severely crowded during peak hours. Hence, it is the busiest railway system and has some of the worst severe crowding in the world. Repetitive movements and awkward posture are the levels of primary risk factors that have been associated with the MSD's.

Aim: To find the incidence of musculoskeletal disorders in train commuters.

Objective: To find out which common joints are involved using Standard Nordic Questionnaire.

Materials and Methodology: An observational study was conducted for the duration of 1 year in metropolitan city with the sample size of 500 healthy adult male and female with age group of 20-40 years who are train commuters travelling during peak hours daily and are included according to the selection criteria. Sampling is convenient. The data was analysed and collected accordingly.

Results: The above data was analysed and it showed Ankles/Feet (17\%) was most commonly affected followed by Knees (16\%) and least was the Elbows (7\%).

Conclusion: This study concluded that the high incidence were seen in the Ankles/Feet followed by Knees and least in Elbows of the train commuters.

KEY WORDS: Musculoskeletal Disorders, Posture.

Address for correspondence: Dr. Satish Pimpale (P.T.), Assistant Professor, DPO's NETT college of physiotherapy, Thane, India. E-Mail: dr.satishpimpale@gmail.com

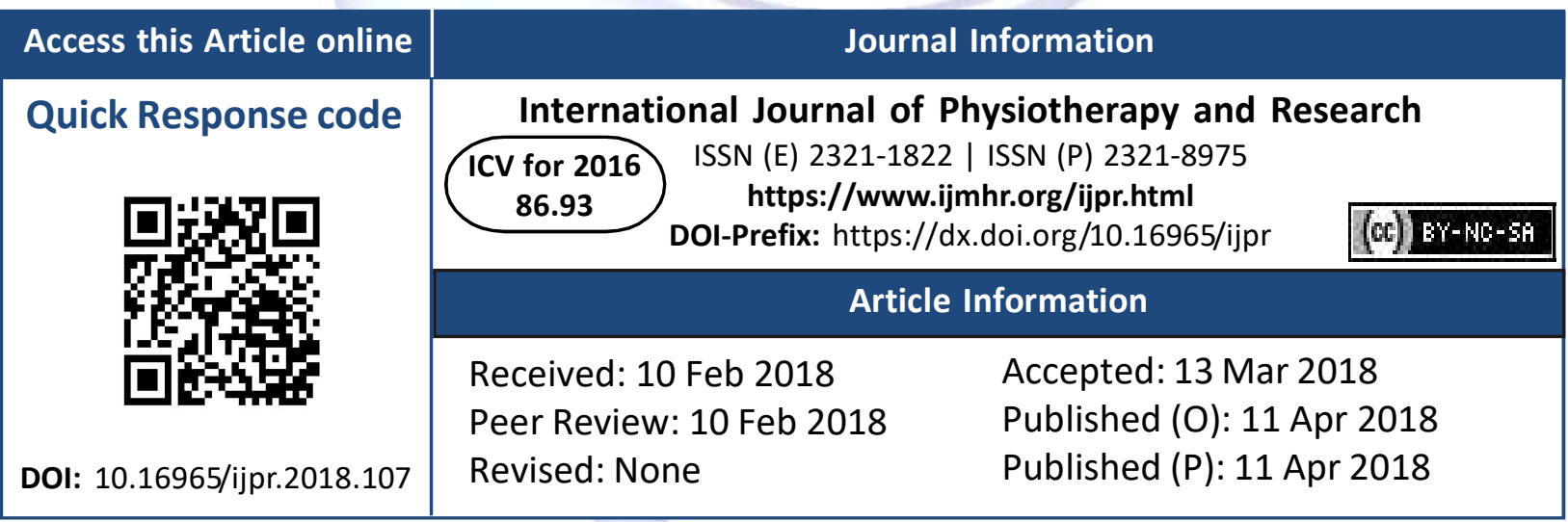

\section{BACKGROUND}

A musculoskeletal disorders (MSDs) is a "A disorders of muscle, tendon, joint, intervertebral disc, peripheral nerves and vascular systems not directly resulting from an acute or instantaneous event but arising gradually and chronically" [1]. Indian railway is the world's largest railway system; in Mumbai suburban railway the daily ridership is about 7.585 million. Therefore, it is the busiest commuter rail system and has some of the worst severe overcrowding in the world [2].

As Mumbai is India's commercial and financial center and one of the most densely populated cities in the world. The cities relies heavily on public transport with about $80 \%$ of all motorized trips being undertaken by the public rail . More than half of these trips is undertaken by the rail system which is the lifeline of the city.

Every day some 8 million commuters use the city's suburban rail system, travelling on more 
than 2,800 trains a day. The network is severely overcrowded during peak hours when the numbers of passengers exceeds the networks carrying capacity by more than four times.

Hence, Mumbai rail network will continue to be the primary mode of transportation in the cities for the year to come [3].

Repetitive movements and awkward posture, and high force levels are the primary risk factors that have been associated with MSD's [4].

Therefore, the problems faced by the commuters are their productive hours are decreased and results in the loss of business and personal human health.

Other problems faced by the commuters in local train are stress, discomfort during journey, accidents and potential for physical injuries. [5]

Need of study: To our knowledge there is very less study on incidence of musculoskeletal disorders in train commuters

During rush hours, many of the train commuters have to travel for their work places, Due to which there will be potential for physical injuries leading to disorders.

Some of the train commuters due to overcrowding have to complete their journey by standing throughout their route.

Whereas, commuters have to compromise in their health to reach their work places, which may lead to physical stress.

Therefore, there is a need to estimate the incidence of musculoskeletal disorders in train commuters.

\section{MATERIALS AND METHODS}

An observational study was conducted for the duration of 1year in the metropolitan city with the sample size of 500 Healthy Adult Male and Female 20-40 years of age who are train commuters. They were selected according to the selection criteria that includes commuters travelling at least for 1 hour of single route per day and travelling during rush hours from 7am-10am \& 6pm-9pm for 6 months; and excludes Commuters travelling in afternoon and night, work related to prolonged sitting and standing for more than $6 \mathrm{hrs}$, handicapped population, recent surgery for less than 6 months, congenital condi- -tions, cardiovascular and neurological conditions.

Procedure: The whole study was explained to the subjects. They were screened as per the inclusion criteria. Subjects not fulfilling the inclusion criteria were excluded from the study. Subjects who were willing to participate in the survey were only considered and a written consent form was taken from them. Demographic data was recorded. A self-reporting Standardized Nordic Questionnaire based on musculoskeletal disorders that includes various parameters related to musculoskeletal disorders were given and explained on how to fill in the details in the language best understood by them. The data was collected and analyzed accordingly.

\section{Outcome Measure:}

Standard Nordic Questtionnaire: It is a selfadministered questionnaire. This is used for the analysis of musculoskeletal symptoms. The reliability of the questionnaire is shown to be acceptable.

Musculoskeletal Discomfort Form (based on the Nordic questionnaire (kourinka of al. 1987)

Job/position:
Gender: $\mathrm{M}$
Age:
Weight_ Height
How long you have been doing this
job?_years_months. How many hours you
work each week?

How to answer the questionnaire:

Picture: In this picture you can see the approximate position of the parts of the body referred to in the table. Limits are not sharply defined, and certain parts overlap. You should decide for yourself in which part you have or have had your trouble (if any).

Left

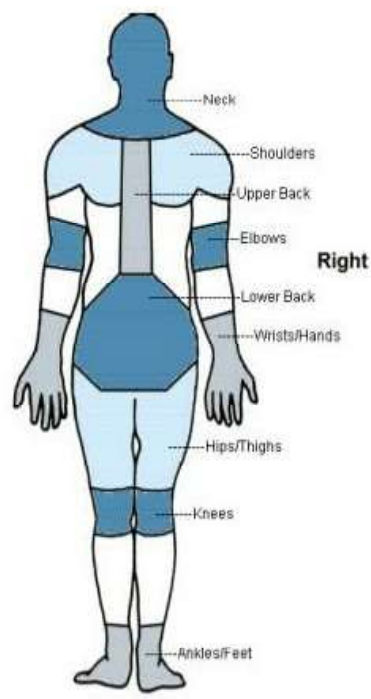


Please answer by putting " $X$ " in the appropriate box-one " $X$ " for each position. You may be in doubt as to how to answer, but please do your Best any way. Note that column I of the questionnaire is to be answered even if you have never had trouble in any part of your body; column 2 and 3 are to be answered if you answered yes in column I.

\begin{tabular}{|c|c|c|}
\hline $\begin{array}{l}\text { To be answered by } \\
\text { everyone }\end{array}$ & \multicolumn{2}{|c|}{ To be answered by those who have had trouble } \\
\hline $\begin{array}{l}\text { Have you at any time } \\
\text { during the last } \mathbf{1 2} \text { months } \\
\text { had trouble (ache, pain, } \\
\text { discomfort, numbness) in: }\end{array}$ & $\begin{array}{l}\text { Have you at any time } \\
\text { during the last } \mathbf{1 2} \\
\text { months been prevented } \\
\text { from doing your normal } \\
\text { work(at home or away } \\
\text { from home) because of } \\
\text { the trouble? }\end{array}$ & $\begin{array}{l}\text { Have you had } \\
\text { trouble at any time } \\
\text { during the last } 7 \\
\text { days? }\end{array}$ \\
\hline $\begin{array}{l}\text { Neck } \\
\square \text { No } \quad \square \text { Yes }\end{array}$ & $\square_{\mathrm{No}} \square$ Yes & $\square$ yes \\
\hline $\begin{array}{r}\text { Shoulders } \\
\square \text { No } \square \text { Yes right } \\
\text { shoulder } \\
\square \text { Yes left } \\
\text { Shoulder } \\
\square \text { Yes both } \\
\text { shoulders }\end{array}$ & $\square$ No $\square$ Yes & $\square$ Yes \\
\hline $\begin{array}{c}\text { Elbows } \\
\square \text { No } \square \text { Yes right } \\
\square \text { elbow } \\
\text { Yes left } \\
\text { elbow } \\
\square \text { Yes both } \\
\text { elbows } \\
\end{array}$ & $\square$ Yes & $\square$ Yes \\
\hline $\begin{array}{c}\text { Wrists/hands } \\
\square \text { No } \square \text { Yes right } \\
\text { wrist/hand } \\
\square \text { Yes left } \\
\text { wrist/hand } \\
\square \text { Yes both } \\
\text { Wrist/hand }\end{array}$ & $\square$ Yes & $\square$ No $\square$ Yes \\
\hline $\begin{array}{l}\text { Upper back } \\
\square \text { No } \square \text { Yes }\end{array}$ & $\square$ Yes & $\square$ Yes \\
\hline $\begin{array}{l}\text { Lower back (small of back) } \\
\square \text { No } \square \text { Yes }\end{array}$ & $\square$ No & $\square$ Yes \\
\hline $\begin{array}{l}\text { One or both Hips/Thighs } \\
\square \text { No } \square \text { Yes }\end{array}$ & $\square$ Yes & $\square$ No $\square$ Yes \\
\hline $\begin{array}{l}\text { One or both knees } \\
\square \text { No } \square \text { Yes }\end{array}$ & $\square$ Yes & $\square$ No $\square$ Yes \\
\hline $\begin{array}{l}\text { One or both Ankles/feet } \\
\square \text { No } \square \text { Yes }\end{array}$ & $\square^{\text {Yes }}$ & $\square$ No $\square$ Yes \\
\hline \multirow[t]{5}{*}{ RESULT } & JOINTS & JOINT PAIN (\%) \\
\hline & NECK & 14 \\
\hline & SHOULDERS & 11 \\
\hline & ELBOWS & 6 \\
\hline & WRIST/HANDS & 7 \\
\hline \multirow{5}{*}{$\begin{array}{l}\text { Table 1: Showing the } \\
\text { body regions and } \\
\text { joint pain }(\%) \text {. }\end{array}$} & UPPER BACK & 8 \\
\hline & LOWER BACK & 14 \\
\hline & HIPS & 7 \\
\hline & KNEES & 16 \\
\hline & ANKLES/FEET & 17 \\
\hline
\end{tabular}

Pie diagram of most incidence of musculoskeletal disorders in train commuters

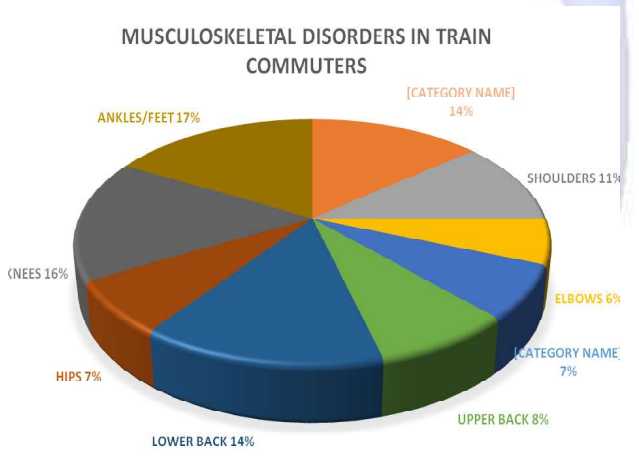

Inference: The above data was analysed and it shows Ankles/Feet (17\%) was most commonly affected followed by Knees (16\%), Lower back $(14 \%)$, Neck (14\%), Shoulders (11\%), Upper back (8\%), Hips (7\%), Wrist/ Hands (7\%) and Elbows $(6 \%)$.

\section{DISCUSSION}

Out of 500 train commuters majority were affected in Ankles/Feet (17\%), followed by Knees (16\%), Lower Back (14\%) and Neck (14\%).

Katherine Craine et al. in their study found that commuting to and from the work everyday can have a profound effect on the body biomechanics. Combination of poor posture combined with inability to stretch it out during the commute makes for quite a bit discomfort for most of the people.

\section{The factors contributing for it are:}

\section{Awkward posture}

2. Everyday wear and tear of Ankles/Feet

3. Overuse of feet

4. Repetitive translatory movements

5. Ligaments causing microscopic tears

6. Prolonged standing in awkward posture

Debarati Sen in their study found that foot pain is common in train commuters who travel for long hours, due to this it causes abnormal walk that affects the spine and you develop back and neck pain, therefore recommended to avoid weight bear on one leg at a time.

\section{The factors attributing for Low Back pain are:}

\section{Slouched sitting posture}

2. Sitting on less surface area with awkward posture

\section{Sudden jerky posture}

4. Twisting

Amenda Macmillan in their study found train commuters faces pain in neck, shoulders, upper back, hips, elbows and hands.

\section{The factors attributing to it are:}

1. Sitting slumped for hours

2. Overuse of shoulders

3. Holding rails and continuously gripping 


\section{CONCLUSION}

This study concluded that the high incidences were seen in the Ankles/Feet followed by Knees and least in Elbows of the train commuters.

\section{ABBREVATION}

\section{MSD's - Musculoskeletal disorders}

\section{ACKNOWLEDEMENT}

It's my great pleasure and privilege to express my deep felt gratitude to the Principal, Guide, and all the staff of DPO's NETT College of physiotherapy for support, co-operation, suggestion and also last but not the least to my almighty for keeping the spirit high and making this project a great success.

\section{Conflicts of interest: None}

\section{REFERENCES}

[1]. Occupational health, WHO, Health related musculoskeletal disorders. Available form http:// www.who.int/occupational_health/publications/ newsletter/newsletter_16_regions/en/index3.html

[2]. Indian railway facts and figures - March 2013.

[3]. Mumbai urban transport project, September 2013

[4]. Silverstein BA, Fine LJ, Armstrong TJ: Occupational factors and carpal tunnel syndrome. Am J Ind Med. 1987, 11: 343-358. 10.1002/ajim.4700110310.

[5]. Travel infrastructure in Mumbai, TRIZ journal 2016.available from https://triz-journal.com/improving-travel-infrastructure-in-mumbai/

[6]. Jain R, Meena ML, Dangayach GS, Bhardwaj AK. Association of risk factors with musculoskeletal disorders in manual-working farmers. Archives of environmental \& occupational health. 2018 Jan 2;73(1):19-28.
[7]. Ng A, Hayes MJ, Polster A. Musculoskeletal disorders and working posture among dental and oral health students. InHealthcare 2016 Jan 23 (Vol. 4, No. 1, p. 13). Multidisciplinary Digital Publishing Institute.

[8]. Ghosh T, Das B, Gangopadhyay S. Work-related musculoskeletal disorder: an occupational disorder of the goldsmiths in India. Indian journal of community medicine: official publication of Indian Association of Preventive \& Social Medicine. 2010 Apr;35(2):321.

[9]. Nordin NA, Leonard JH, Thye NC. Work-related injuries among physiotherapists in public hospitals: a Southeast Asian picture. Clinics. 2011;66(3):373-8.

[10]. Moom RK, Sing LP, Moom N. Prevalence of musculoskeletal disorder among computer bank office employees in Punjab (India): a case study. Procedia Manufacturing. 2015 Jan 1;3:6624-31.

[11]. Janwantanakul $P$, Pensri $P$, Jiamjarasrangsri $V$, Sinsongsook T. Prevalence of self-reported musculoskeletal symptoms among office workers. Occupational medicine. 2008 Jun 10;58(6):436-8.

[12]. Glover W, McGregor A, Sullivan C, Hague J. Workrelated musculoskeletal disorders affecting members of the Chartered Society of Physiotherapy. Physiotherapy. 2005 Sep 1;91(3):138-47.

[13]. Bapkurt F, Bapkurt Z, Gelecek N. Prevalence of selfreported musculoskeletal symptoms in teachers. SDÜ Saðlýk Bilimleri Enstitüsü Dergisi Cilt. 2011;2(2):58-64.

[14]. Porter JM, Gyi DE. The prevalence of musculoskeletal troubles among car drivers. Occupational medicine. 2002 Feb 1;52(1):4-12.

[15]. Alipour A, Ghaffari M, Shariati B, Jensen I, Vingard E. Occupational neck and shoulder pain among automobile manufacturing workers in Iran. American journal of industrial medicine. 2008 May 1;51(5):372-9.

\footnotetext{
How to cite this article:

Vrushali Rajesh Patil, Satish Pimpale, Ajay kumar. INCIDENCE OF MUSCULOSKELETAL DISORDERS IN TRAIN COMMUTERS. Int J Physiother Res 2018;6(2):2660-2663. DOI: 10.16965/ijpr.2018.107
} 